Fikrah: Jurnal Ilmu Aqidah dan Studi Keagamaan

ISSN 2354-6147 EISSN 2476-9649

Tersedia online di: journal.stainkudus.ac.id/index.php/fikrah

DOI: 10.21043/fikrah.v6i1.2614

\title{
The Implication of Caliphate Ideology Movement against the Implementation of Democracy toward Jember Society
}

\author{
Moh. Abd Rauf \\ Institut Agama Islam Negeri Jember, Indonesia \\ raufthehacker18@gmail.com
}

\begin{abstract}
Abstrak
Internalisasi gerakan ideologis khilafah oleh beberapa organisasi masyarakat bergulir sejak era reformasi karena penyediaan ruang kebebasan umum. Salah satu organisasi yang memaksakan mendirikan khilafah adalah Hizbut Tahrir Indonesia (HTI). Tulisan ini mencoba mengungkap konsep ideologi dalam perspektif HTI dan bagaimana mereka menginternalisasi gerakan khilafah menuju eksistensi demokrasi di Jember Jawa Timur Indonesia. Artikel ini menggunakan jenis artikel empiris dengan pendekatan fenomenologis. Hasilnya menunjukkan bahwa demokrasi pada hakekatnya mewakili pemerintah dan kekuatan tertinggi suatu negara. Sistem pemerintahan demokratis mengikuti prinsip pemerintah dari rakyat, oleh rakyat, dan untuk rakyat. Gerakan khilafah sangat berpengaruh dalam merongrong nilai demokrasi yang dikenal sangat komprehensif. Pada saat ini gerakan ini meluas ke berbagai daerah, terutama di kota Jember dalam mengubah paradigma umum masyarakat untuk mengikuti ideologi tersebut.
\end{abstract}

Kata Kunci: Ideologi khilafah, Hizbut Tahrir Indonesia, masyarakat perkotaan, fenomenologi 


\begin{abstract}
The internalization of the caliphate ideological movement by several community organizations rolled since the reform era because of the provision public freedom space. One of the organizations that forced to establish the caliphate was Hizbut Tahrir Indonesia (HTI). This paper tries to reveal the ideology concept in the HTI's perspective and how they internalize the caliphate movement toward the existence democracy in Jember East Java Indonesia. This research uses a type of empirical research with phenomenological approach. The result show that democracy is essentially represent the government and the supreme power of a state. The system of democratic government follows the principle of government from the people, by the people, and for the people. The movement of caliphate was very influential in undermining the value of democracy is known to be very comprehensive. At this time the movement is expanding to various regions, especially in Jember city in changing the general paradigm of society to follow the ideology.
\end{abstract}

Keywords: Caliphate ideology, Hizbut Tahrir Indonesia, Urban Society, phenomenology

\title{
Introduction
}

The end of the new order power in 1998 opened the space for Indonesian citizens to express their political and socio-economic views (Hamayotsu, 2013). Identity-based groups begin to express their importance. One is the Islamic group. Islamic groups have an open opportunity to voice their interests, especially in the political system of Indonesia. The group was later known as the Islamic Political term. The group that strives for the upholding of Islamic values in the party or non-party system. Ones of Islamic ideological movement are Hizbut Tahrir (HT). HT as a transnational movement spread in over forty-five country in the Asia, Europe, Africa, and Middle Eastern (Karagiannis \& McCauley, 2006; Mohamed Osman, 2010). The HT mission is restoring the past Islamic caliphate (Ahnaf, 2009).

Those who fight for the enforcement of Islamic law through non-partisan channels are sufficiently independent in carrying out movement activism. The effort was taken because they considered the democratic system as a system of disbelief, or not based on Islamic law. Establishing a party and contesting in the elections is the same as acknowledging the upholding of the system of disbelief. Groups included in this category are Hizbut Tahrir Indonesia (HTI). Hizbut Tahrir is not a religious organization, it claimed by their self that HT is an international Islamic movement. Their goal are for unification of all Muslim countries into a single state (Karagiannis \& McCauley, 2006). 
The previous research done by Mastur (2011) discusses caliphate discourse in Indonesia. Therefore Selly (2008) conclude that Hizbut Tahrir understands the concept of nation state in the era of globalization has been obsolete. Hizbut Tahrir views the system of the Islamic caliphate government as an alternative solution to globalization crisis. Ambarita (2014) which escribe one of the influence of caliphate ideology on da'wah activity. The discussion that the way Dai and Muslim scholars preach the Caliphate movement through facebook in Bengkulu. Zulfadli (2010) explains in detail the response of Islamic organizations to politics in Indonesia. This paper wants to specify more to respond the ideology of HTI's caliphate towards democracy. The study also wants to provide space for the response of local communities, especially Jember region East Java Province Indonesia in responding to the Caliphate movement towards democracy.

\section{Method}

This research is an empirical research with phenomenological approach that is trying to describe factual condition that happened on discourse of HTI in Jember. This approach is a qualitative content analysis approach with no emphasis on the quantity of words in a news or article text but emphasizes the theme/ topic as the discourse that appears on the HTI site. In this study the type of data collected consists of primary data and secondary data. Primary data is data obtained directly from the data source in the field (field research). This primary data was obtained by using questionnaires, interviews, and observations. And secondary data is obtained from text on the HTI website hizbuttahrir.or.id, journal, papers, and thesis and as well as some news published by local pages about the existence of HTI in Jember City. Researcher tries to reveal the influence of the caliphate ideological movement by HTI to the implementation of democracy in Jember city.

\section{The Relation between Democracy and Islam}

The Indonesian management of religion has not resulted in spirituality but more problems with state administration (Seo, 2012). Religion and Democracy Relationships discussing religious and democratic relations, in this case there are three views or 
models (Salim \& Ubaidillah, 2000, p. 5). Paradoxical or negative model which states that between religion and democracy cannot be converged even opposite (religion versus democracy). The views of the viewers are Karl Marx, Max Weber, Nietzche and Satre. There are at least three arguments about the disparity between religion and democratization. Firstly, the sociological-historical argument explains that religious history provides an illustration of religious roles not only rarely used by political authorities and leaders of religious organizations to support the interests of the group. Secondly, the philosophical argument stating that the attachment to the religious doctrine would shift the autonomy and independence of people which also meant shifting the principles of democracy. Thirdly, the theological argument confirms that religion is deductive, metaphysical and makes its reference to God, while God is not empirically present, while democracy is empirical, concrete and dynamic. So religion does not have the competence to solve democracy issues.

The Indonesian people have more Muslims than any other country in the world. This has an impact on the shape and trajectory of the Indonesian people. Islamists have found so little attraction in Indonesia's political constituents (Elson, 2010). Discussing Islam's relationship with democracy is essentially axiomatic. The reason for Islam is a religion and a pamphlet containing the principles governing the worship, morals and muamalat of human beings. While democracy is only a system of government and the mechanism of work among members of the community as well as symbols that are believed to bring many positive values. The polemic relations of democracy with Islam are rooted in a theological tension between the thirsts of understanding the doctrines that have been established by the history of Muslim dynasties with the demands to give a new understanding of the doctrine in response to the ever-growing social phenomenon (Al-Fandi, 2011, p. 50). There are three basic thought about Islamic discourse and democracy. According to Alim (2010, p. 159) the democratic state: Syura (deliberation as an Islamic democracy) is characterized by freedom of speech and expression, freedom from fear, freedom of communication and information, freedom of choice of residence, equality, equality of men and women, the right of asylum Politics, rights and obligations to defend the state, and the right to the protection of personal freedom. 
First, Islam and democracy are two different systems. This group is often referred to as an Islamic or ideological Islamist group, which views Islam as an alternative system of democracy, so democracy as the western concept is not rightly used as a reference in the life of nation and state. The logic they use is a democratic government coming from the west and west is not Islam so the west is infidel. All the unbelievers are guilty of sinning following a democracy for true Muslims its sinful. In short, according to this group democracy is a pagan system because it has placed the nation's sovereignty in the hands of non-God's people. This group was represented by Taqiyuddin An-Nabhani with his party Hizbut Tahrir who strongly opposed the ideas of democracy and argued that most of the democratic activities were rejected syar'i. They perceived that the principle of elections clearly violates the wakalah principle, that is, the material represented based on the basis of democracy, which Hizbut Tahrir views is false.

Second, Islam is different from democracy. This group agrees with the principle of democracy in Islam but still acknowledges the difference between Islam and democracy if democracy is defined procedurally as understood and practiced in western countries. Conversely, if democracy is substantially interpreted, namely the sovereignty of the people of Islam is a democratic political system. Democracy is a concept that is in line with Islam after the adjustment of the interpretation of the concept of democracy itself. Among the Muslim leaders who supported this view were Abul A'la alMaududi who claimed that western secular democracy, the government was formed and changed by the election. Democracy in Islam also has similar insights, but the difference lies in the fact that if in the western system a democratic state enjoys absolute sovereign rights. In the Islamic democracy the caliphate is set to be limited by the boundaries outlined by the divine law.

Third, Islam justifies and supports democracy. This group is often referred to as a moderate or liberal group. According to this group Islam is a value system that justifies democracy as it is now practiced in developed countries. This acceptance is due to what is deemed as the principles of democracy as it is also contained in the teachings of Islam such as justice, equality, rites and so forth. In the Indonesian context there are Majelis 
Ulama Indonesia (MUI) who concern with their fatwa about democracy, pluralism and religious minorities and explores their socio-historical contexts (Nasir, 2014).

If democracy as an idea based on the principles of liberty, equality, and human sovereignty to determine matters relating to public affairs, then fundamentally in line with Islam. This will at least be seen in two ways (Ghofur, 2002, p. 41). Firstly, in Islamic teachings about the values of life that should be used as reference, namely Al-musawah, Al-hurriyah, Al-ukhuwwah, Al-'Adalah, Al-shura, Al-Mas'uliyyah. Secondly, Islamic teachings on the rights that must be pursued by the self or the society / state that include Hifdz al-nafsi (right to life), Hifdz al-din (religious rights), Hifdz al-'aqli (the right to think), Hifdz al-mal (individual property rights) and Hifdz al- 'irdh (the right to defend the good name).

\section{The Relation of Religion and State based on Islamic Perspective}

There is a strong collective memory among Muslims, there is a doctrine that reads al-Isläm huwa al-din wa'l-dawlah, and Islam is a religion and power. Implications of this relationship, between religion and state, between ritual and political aspects, are closely related, and even inseparable. The legal aspect touches on all socio-political aspects. Since the Prophet Muhammad until now, memories of Medina the place where the Prophet began to pluck success in da'wah and built his society very powerful (Hidayat \& Nafis, 2003, p. 93).

Although Islam is believed to provide guidelines for all aspects of life, particularly regarding political or political affiliation, it turns out that the relationship between religion and the state in Islam is very poly interpretable, rich in interpretation. In Islam, political thought about religious and state affairs is still a hot debate among experts. Globally, at least there are at least three paradigms of thought about religious and state affairs. First, a paradigm that says Islam has nothing to do with the state, because Islam does not regulate state life or government. According to this paradigm, historically the area of the Prophet Muhammad against the believers is a territory of treaties not interfered by the tendency of government. Some famous figures who support this concept are 'Ali Raziq and Thaha Husein. The second paradigm assumes that Islam is a perfect religion, which includes everything, including state problems or 
political systems. The main characters of this paradigm are Hassan al-Banna, Sayyid Quthb, Rasyid Ridha and of course Abu al-A'la al-Maududi. The third paradigm, rejects the idea that Islam covers everything and also rejects the view that Islam only regulates the relationship between man and his Creator alone. This paradigm argues that Islam does not cover everything, but includes a set of principles and ethical values of social life including statehood. Famous figures in this paradigm are Muhammad 'Abduh and Muhammad Husein Haikal.

\section{Secularicstic Paradigm}

'Ali' Abd al-Raziq explains his views with some principles. First, there is no caliphate system in the Qur'an and the Sunnah. According to Raziq, caliphate is a general leadership in religious affairs and the world replaces the Prophet. The definition indicates that for Muslims, the position of a khalifah is in the position of the Messenger of Allah (SAW), which does not only address the religious issues but also the problems of the world. Khalifah is a representation of a religious ruler as well as world politics. With that argument, accepting the power system of the caliphate is an obligation to realize religious and government messages that pay attention to the interests of the people.

'Abd al-Raziq rejects all of the above reasons. According to him, the Qur'an does not raise the question, in addition to just general statements in order to respect those who hold power. Hadith also does not express opinions, in addition to the general statement of adherence to the imam, without any clear definition of the function of the imam or the statement of its necessity. Even if the hadith really refers to khalifah when saying about the imam, this does not imply that there should always be a khalifah.

Secondly, Muhammad is an Apostle not a ruler of the state. 'Abd al-Raziq observes when Muslims are generally inclined to the belief that the Prophet is a Messenger as well as a political ruler, he is a religious ruler and a government leader. The Muslim community tends to assume that Islam is a political and religious unity fundamentally built by the Messenger of Allah, no matter how Ibn Khaldun even thinks so in his Muqaddimah work. 
In the Qur'an there is the term uli al-amr which generally means obedience to the leader, for example in Surat al-Nisa the following verse 59:

"O ye who believe! Obey Allah and obey the Messenger, and ulil al-amr among you."

But the term uli al-amr in the verse, for 'Abd al-Raziq, contains no proposition that is suitable to apply to the obligatory obligation of the deceased. The maximum content of the term is that it is imperative for Muslims to have a group of people who can be dictated references to the questions they face. That is the wider meaning, the richer, and more general than just the meaning of caliphate. In this context, it is interesting to see Quraish Shihab's perspective on the various meanings of al-amr in his tafsir, al-Mishbah. In the view of Quraish, in the sense of uli language is the plural form of wāliy which means the owner or who takes care or controls. The plural form of the word indicates that they are many, while the word al-amr is a command or affair. Thus uli al-amr is the person authorized to take care of the affairs of the Muslims. They are people who rely on dealing with social issues. From here, the term uli al-amr may be drawn to several meanings: a) They are rulers (rulers); B) They are clerics; and c) They are people representing the community in various groups and professions both formal and informal (such as police) or non-formal (like scientists / scholars). Thus, it is not appropriate to limit the meaning of uli al-amr to a khalifah or caliphate system alone.

Up to this point, 'Abd al-Raziq does not offer a system of government or any form of political power, whether it is a system of monarchy, aristocracy, oligarchy, theocracy, or democracy. Everything is left to the human ratio and according to social settings of each community, because each community, space, and time has its own uniqueness that is not owned by others so the solution must be unique too. Of course, read by Armstrong and other observers from the West is not a rigid Islamic political concept that is to establish an Islamic state. But how to implement principles of principle in Islam into a government level that is not only useful for Muslims but also for other non-Muslim communities, as exemplified by Muhammad in the past. In other words, socialize the values of Islam that are inclusive and pluralist so they can protect all social altitudes. 
Despite the many critics thrown by thinkers on 'Abd al-Raziq, the idea of Abd al-Raziq still has its own significance. At least the concepts are the result of ijtihad against Islam on the freedom of reason that today is still appreciated by contemporary thinkers in enriching the political discourse in Islam. What's more, nowadays there are so many fundamental movements wishing to reconstruct the system. Classical Islamic reigns literally and in fact the majority of Muslim countries until today still fail to form a democratic political system. The liberal offer of 'Abd al-Raziq may be a reflection that it is not just religious norms that must play but also human liberation must be given space to speak extensively.

\section{Formalistic Paradigm (Integralistic)}

The formalistic paradigm looks at the religion of Islam as a perfect and complete religion, which includes not only the moral guidance and the worship, but also the instructions on how to manage all aspects of political, economic, and social life. Therefore, for the recovery of prosperity and prosperity, Muslims must return to its perfect and comprehensive religion, return to its holy book, the Qur'an and Sunnah of the Prophet SAW, modeling the lifestyle of the Messenger of Allah and the first generation of Muslims, and not necessary or even Do not imitate the political, economic, and social patterns or systems of the west. Political aspect that wants to make Islam as the foundation of government in all dimensions is what is shown by the Muslim Brotherhood movement in Egypt and has a considerable influence on Muslims in different parts of the country. The declaration of the need to return to fundamental Islamic teachings with targets of the Islamic caliphate or to establish an Islamic state with the patronage of the Prophet and four companions began pioneering by Hassan alBanna, Sayid Quthb, Said Hawwa, and others.

Hassan al-Banna, the founder of the Muslim Brotherhood movement, explained that one of his mission missions was to establish an Islamic state, established on Islamic teachings, apply social rules, advocate the principles of truth and spread its propaganda to all humanity. Al-Banna warns Muslims in general that throughout such a country there is no one, every Muslim is sinners and they are responsible before God for their failure and negligence to establish it. Al-Banna also considers political parties as a potential threat to the Islamic unity for which the people are required to rebuild the caliphate. 
Simply stated, it is said that the movement of the Muslim Brotherhood is a political movement that is a movement that demands internal remedial action against the government, straightening the perceptions related to the relationship of Muslims to other nations abroad, educating the nation in order to have the glory and preserve its identity. The phrase also explains that political aspects relate to what is related to state governance and the relationship between government and the people. Likewise interstate relations, with occupiers, and related issues. In other words, politics is an attempt to think about internal and external issues of Muslims.

Political internal dimensions take care of governmental issues, explain its functions, detailing its obligations and rights, overseeing rulers for later compliance if they do well and are criticized if they make a mistake. Whereas external dimensions, preserving the independence and freedom of the nation, deliver it to the goal that will position itself in the midst of other nations, and free it from the oppression and intervention of others in its affairs. Therefore, what is implied behind his textual appearances is almost neglected, if not forgotten. In extreme examples, this tendency has hindered Muslims from being able to clearly understand the messages of the Qur'an as a Divine instrument that provides the correct moral and ethical guidance for human life.

\section{Substantialistic Paradigm (Symbiotic)}

In a substantial paradigm, Islam has a set of principles and values about social life, including the system of government. In the perspective of Muhammad 'Abduh, the reality of Islamic rule is not religious but it is truly worldly. 'Abduh states that political power must be based on people's sovereignty or public will. The sovereignty of the people, according to 'Abduh, must be built on the basis of the principles of freedom (hurriyah), democracy (shūrā), and the constitution (qanūn) that serve as the foundation of this political system and power. Abduh's conception of freedom includes social and political freedom, including freedom of expression, freedom of speech, freedom of choice, and even freedom for women in gaining their rights. If these values can be applied in political life, then the relationship between the ruling and the ruling will take place in positive and constructive interactions. According to 'Abduh, Islam 
does not recognize religious authority in the sense of: a) Islam does not give power to a person or group of people to take action on others in the name of religion or based on a mandate from religion; b) Islam does not allow one's intervention, his or her control, in the life and religious affairs of others; And c) Islam does not recognize a person's right to impose his understanding, opinion, and interpretation of religion on others.

'Abduh admits that Islam is not a mere religion, but has laws governing the relationship between Muslims and fellow beings, which for the implementation and monitoring of the occurrence require the existence of a complete ruler with its apparatuses. He said that the task was the responsibility of the head of state and its government apparatus. But the head of state as a civilian ruler is appointed by the people and is responsible to the people. People are the real owners of power and who have the right to lower the head of state from the throne of his power. The head of state is not a representation or shadow of God on earth, which requires every Muslim to obey him for the sake of religion despite his or her behavior or nature contrary to religious teachings.

According to some observers, through some of his ideas, 'Abduh is trying to reconcile between Islamic and Western ideas. 'Abduh for example suggested that mașlahah (interest) in Islamic thought in accordance with the utility in Western thought. Likewise he likens shūrā to democracy, and ijmā 'with consensus. 'Abduh believes that Islam's relationship with the modern world is a crucial issue that Muslims must face. So here, though 'Abduh believes the Islamic doctrine includes the principles of social and political life, but he refuses if the system of government should be Islamic state or islāmiyyah caliphate, by returning to classical era. For Abduh, the question of the form of government in Islam is entirely devoted to the reasoning of Muslims, though it must continue to apply the principles of freedom, justice, harmony, peace, and egalitarianism. With this kind of argument, the establishment of an Islamic state in its formal and ideological sense is not very important. For them, the most important thing is that the state because of its position that can be instrumental in realizing religious teachings ensures the growth of such basic values. If so, there is no theological or religious reason to reject political ideas about the sovereignty of the people, the nations as legitimate territorial units, and the general principles of other modern political theories. In other words, it is not a strong reason to put Islam in a position that is contrary to the modern political system. 


\section{The Caliphate Ideology Concept of HTI's Perspective}

The history of HTI could be divided into two main periods. The first period is during the New Order regime of Suharto and the second period is during the post New Order period (Mohamed Osman, 2010). The beliefs of some Islamic figure in the past that Islam embraced a system of belief and politics and there was a direct connection between Islam and the state. The development of political Islam itself among Islamic leaders is a natural thing, because every political struggle requires ideological legitimacy. The emergence of political Islam is also a form of Muslim resistance to colonial power and western domination. Or as a result of internal factors, namely in the form of a change of political power map, the weakening of ideological competition between political forces and the emergence of new forces that try to dominate, both economically and culturally (Riyadi, 2008, p. 32).

Further developments, changes in political discourse that continue to roll both at local and global levels are expected to produce the ideal concept that is offered towards a more realistic thinking. Similarly, in the discourse of the Islamic system of government, of course expected to formulate an ideal concept, which is not only rational-realistic, but also not out of the frame of Islamic teachings. At least the idea is a contribution that enrich the treasures of Islamic political movements and thought. At once as empirical evidence that religious values have given Muslims a common ground to communicate, build solidarity, cultivate commitments, work together and develop common goals on the political stage. HT ideas based on anti-integration agenda, an open rejection of democracy, personal freedom and Western foreign policy, HT seen that potentially dangerous (Orofino, 2015).

The discourse of Islamic politics by the scholars themselves in the conversation of religious and political relations leads to two purposes. First, find the Islamic ideal of politics (doing theoretical and formal aspects), for instance trying to answer the question 'what form of state or Islamic government'. Second, idealizing from an Islamic perspective on the process of state or government administration (emphasizing the praxis and substantial aspects), for instance trying to answer the question "how the content of the state according to Islam". If the first approach departs from the 
assumption that Islam has a certain concept of state and government, then the second approach is based on the notion that Islam does not bring about certain concepts of state and government but merely brings the basic principles of ethical and moral values.

Hizbut Tahrir and HTI, with the concept of caliphate, apparently using this idealistic approach. Hizbut Tahrir claims that the Caliphate has positive dimensions not possessed by the form of the state with such limits. Other countries are part of the Caliphate state. Meanwhile, in the form of a modern state today one country dominates another country based on its national interests. With the caliphate system can be avoided domination and hegemony of one country to another country both in the form of physical colonialism and non-physical. The question is, whether the predominantly Muslim countries that are currently established in the form of a nation state are willing to merge or become part of the Caliphate state. Both Hizbut Tahrir and HTI do admit that there is no Qur'anic text that obliges the adherents to establish the Caliphate. Obligations were obtained in the contextual perspective of the message of the Qur'an, let alone see the current conditions in which the unity of Muslims increasingly fragile.

Moreover, according to the Hizb's view, the life of Muslims today is in an unIslamic situation, as a result of the enactment of a secular system which in many ways contributes greatly to the creation of very poor social conditions. Various violations, both criminal and civil law violations, for example, are committed by many people. But the system is barren to enforce the law. According to HTI, Islam has a system that can lead to good. Therefore, what must be done is to replace the existing system with the system provided by Islam. Islam must be presented and become ideological religion through dawlah Islamiyah with the caliph as its ruler. Thus, it can be reiterated that the concept of caliphate initiated by Hizbut Tahrir is an ideal concept in the formation of Islamic politics. But regardless of agree or not to the concept of the caliphate, See the current political reality, then the concept will be difficult to realize.

\section{The Internalization of Caliphate Ideology Movement}

HTI views, democracy cannot afford welfare for the people. HTI discloses the huge amount of Indonesia's debt. In fact, according to him, Indonesia is the largest democracy in the Islamic world. In saying "democracy in Indonesia is the largest 
democracy in the Islamic world but the fact that democracy is being implemented, Indonesia's debt is getting bigger". HTI considers democracy as a system that causes Indonesia to owe it to other countries. In other words, between democracy and the wellbeing of the people there is no connection with each other. HT activists convey their message that poverty and inequality can be overcome when corrupt governments are replaced by sharia rules. HTI criticizes corruption, inequality and oppression of Muslims (Yilmaz, 2010).

The democratic system itself becomes the cause of corruption so it is impossible to eradicate. A democratic system is an impossible system to eradicate corruption as people want. The reason is democracy requires huge political costs. According to HTI, the 2014 general election will be more corrupt than the previous general election. Democracy says he will not achieve any goal. In the news, HTI also linked that democracy as a means of protecting American interests. So, if there are any rules or policies that are against the interests of America, surely America will never be willing. Whatever the purpose to achieve through the path of democracy will definitely fail. Democracy will never be willing if there are rules or policies that contravene the interests of the current strongest invaders state of the United States. The HT agendas are challenging western country like United States both politically and socially (Orofino, 2015).

HTI looks at the implications of the implementation of democracy in religious and theological aspects (religion). In the view of HTI, democracy can lead Muslims to shirk or fellowship of God because democracy means human beings are arrogant and arrogant by becoming God's competitor in terms of making human rule of life. Democracy by HTI is a crippling system that fails to build civilization. Damage has been seen in the face of democracy. HTI also said that the nation had repeatedly held elections and replaced its president, but did not make any change. The path of democracy is not designed to produce fundamental changes. The way of democracy can make Muslim activists a ruler but does not give them the opportunity to apply Islamic law. On the HTI's perspective democracy has failed to create political stability and clear government. In fact, democracy is more concerned with capitalists and political investors than people. Executives and legislative governments have plotted only to 
perpetuate their power without thinking of the interests of the people. HTI criticizes that in Indonesia there is a paradox. The richness of nature is overwhelming but the people live poor and backward. This is due to the application of the democratic system.

HTI also links democracy with decadence or moral damage to society. According to him, democracy is a man-made system that will not bring prosperity to the people, even democracy will not bring about change for Indonesia to be better. Democracy that dumps God's laws has brought damages. Moral and moral are very corrupted. Pornography, adultery, spread everywhere. The rejection of HTI on democracy is also due to the consideration of the understanding of religious doctrine. In the perspective of HTI, democracy is a system of kufur, not sourced from God as stated in an article titled "Telanjangi Demokrasi", Published May 30, 2014. In addition to ideological reasons based on an understanding of Islam, HTI rejected democracy as well because of this system is believed to be unable to pursue the people, who are prosperous only rulers and entrepreneurs. Because of this consideration, democratic products will not harm the people. Related to the party of democracy or elections held by Indonesia in 2014, HTI views that the election will not be able to harm the people of Indonesia.

Democracy in the view of HTI does not create a better condition but creates a poor condition because of the establishment of a corporate system. HTI proposes to adopt the caliphate government system. Democracy is also constructed as a cause for Indonesia to remain in full independence. Democracy has transformed Indonesia's prosperous and wealthy natural resources into a country that has never managed to be 100 percent independent and independent. HTI sees that Indonesia is still in colonization not physically but economically. The Indonesian civilization is due to Western domination (Beritasumut, 2014).

On behalf of democracy, the country is directed by capital interests (capitalists). Therefore, the leader in the democratic system actually run the wheels of government is not based on the people's consent, but for the interests of the elite and the powerful cronies, including the interests of capital owners. Meanwhile, the ideology of secular capitalism decreases the role of religion in the context of government administration. The administration of ideology-based ideology of secular capitalism through the mode 
of the democratic system also makes its leaders ignore spiritual values. The orientation of governance is solely concentrated on pragmatism and materialistic gains. As a result, a figure of ignorant leader was born as a benchmark when administering the wheels of government.

The liberal economy is the cornerstone of various national economic problems. The deprivation of natural wealth by foreign capitalists, poverty, the abandonment of community needs such as education and health are the fruit of the liberal economic system applied because it requires the state not to play a role in nurturing and serving the needs of society. Instead, the role was left to the private sector in the form of business affairs alone (Infokomhti, 2014).

According to HTI, democracy practice at least obstructs one of the conditions of taqwa which is to practice the Quranic and Hadith laws, companion's striving, and qiyas. So, according to HTI cannot be said to be pious if they do not want to run Islamic law. The mechanism of applying God's law at state level is to directly apply it without the consent of the majority of members of the House of Representatives (DPR). On the contrary, democracy makes Indonesia broken and damaged. Indonesian politics has implemented democracy in various forms, namely liberal democracy, guided democracy, Pancasila democracy, and liberal democracy. However, the democratic system cannot make Indonesia a prosperous country. Indonesia fails to become a prosperous country. On the contrary, democracy is a source of trouble. HT analyzed the absence of application of Islam was the core problem of the Muslim world (Hanif, 2012).

\section{Jember Case}

Jember is one of cities in East Java whose majority societies have a religious or religious style. As a religious city there has been growing stream of religious social organizations. Likewise, Islamic organizations are able to grow and maintain their existence. HTI as one of the Islamic organizations in Jember city is also able to color and enrich the way of Jember society in implementing Islam's value. However, the influence of the existence of HTI movement is not too massive in Jember city due to several factors. First, from strong social culture side against traditionalist Islamic basedon 
pesantren. Pesantrens can grow and develop rapidly because of the permissive attitude of the Jember community to Islam that is able to dialogue with the local culture of the local community. The well-known pattern of HTI movements is more likely to modernism and seeks to eliminate its local cultural roots. This fact is reinforced by Abdullah Syamsul Arifin's opinion as Chairman of the PCNU Jember which stated;

"The HTI movement that strives for the Islamic caliphate is not only in Indonesia but transnational, so the HTI movement is different from that which is fought by a number of boarding schools in Jember which is miniature NU."

Secondly, from the political factor, HTI is known as a political party in fact not participate in the political stage in Jember. Thus, Jember society more justify that HTI movement undermining the process of democracy in Jember city. In addition to the statement Chairman PCNU Jember added:

The government to build the state is legitimate and in accordance with Islamic Shari'a, so the formulation of the current state of independence up to now with the democracy, Pancasila, UUD 1945, and NKRI as the four pillars of nationality is a system of government that can accommodate all the children of the nation in diversity. There is no standard system established in Islam after the death of the Prophet related to the turn of leadership in Islam. That is, in the context of HTI has imposed itself and have no strong proposition on it.

Third, from socio-religious factor. The predominantly Muslim city of Jember prefers to adopt moderate Islamic groups such as NU and Muhammadiyah. HTI teachings that are judged to be more fundamental to teachings have sparked rejection from other Islamic organizations that ultimately lead to conflicts and friction that disrupt the stability of security. In this case the Secretary of Teachers Union Nahdlatul Ulama (Pergunu) who is also the caregiver of Pontifical Ponpes Almahrus KH Mustain Billah opinion:

First, reject firmly all HTI activities in Jember in particular and in Indonesia in general because HTI is an organization that promotes caliphate that will change the ideology of Pancasila State and knock down the NKRI building. Second, HTI followers must return to the Islamic teachings of Ahlussunnah waljamaah in the framework of the Unitary Republic of Indonesia and thirdly, asking and urging the government to immediately dissolve HTI and other similar organizations that are clearly anti-NKRI, if not want horizontal conflict in Indonesian society. 


\section{Conclusion}

The concept of the HTI's caliphate ideology is incompatible with the concept of a democratic country which is running in Indonesia. For want of a centralistic leadership headed by a kholifah different from the presidential government system adopted by Indonesia. Meanwhile, the ideology of HTI's Caliphate in Jember City did not significantly contribute to the existence of democracy in Jember. This is because it is influenced by three factors namely; Cultural factors, political factors, and socio-religious factors. The central and regional governments are expected to monitor fundamentalist/ separatist Islamic movements that threaten the existence of democracy in Jember City. The organization is expected to be able to cooperate with the government with other relevant parties in stemming the flow of treason movements that potentially threaten the security and religious stability in the city of Jember. The results of this study are expected to contribute thoughts and can be used as reference materials for further research related to the ideology of the HTI Caliphate. 


\section{Reference}

Ahnaf, M. I. (2009). Between revolution and reform: The future of Hizbut Tahrir Indonesia. Dynamics of Asymmetric Conflict, 2(2), 69-85. http://doi.org/10.1080/17467580902822163

Al-Fandi, H. (2011). Desain pembelajaran yang demokratis \& humanis. Ar-Ruzz Media.

Alim, M. (2010). Asas-asas Negara Hukum Modern dalam Islam: Kajian Komprehensif Islam dan Ketatanegaraan. LKiS.

Ambarita, F. (2014). Aktivitas Dakwah Ideologi Khilafah Melalui Pemanfaatan Facebook (Studi Pada Dai dan Cendikiawan Muslim di Kota Bengkulu). Universitas Bengkulu.

Beritasumut. (2014). HTI Kembali Kritisi Sistem Demokrasi Indonesia Portal Berita Sumatera Utara. Retrieved from http://beritasumut.com/Politik--Pemerintahan/HTI-Kembali-Kritisi-Sistem-Demokrasi-Indonesia

Elson, R. E. (2010). Nationalism, Islam, "secularism" and the state in contemporary Indonesia. Australian Journal of International Affairs, 64(3), 328-343. http://doi.org/10.1080/10357711003736493

Ghofur, A. (2002). Demokratisasi dan prospek hukum Islam di Indonesia: studi atas pemikiran Gus Dur. Kerjasama dengan Walisongo Press [dan] Pustaka Pelajar.

Hamayotsu, K. (2013). The Limits of Civil Society in Democratic Indonesia: Media Freedom and Religious Intolerance. Journal of Contemporary Asia, 43(4), 658-677. http://doi.org/10.1080/00472336.2013.780471

Hanif, N. (2012). Hizb ut Tahrir: Islam's Ideological Vanguard. British Journal of Middle Eastern Studies, 39(2), 201-225. http://doi.org/10.1080/13530194.2012.711037

Hidayat, K., \& Nafis, M. . (2003). Agama Masa Depan: Perspektif Filsafat Perenial. Jakarta: Gramedia.

Infokomhti, G. (2014). Warga Garut Tolak Demokrasi dan Ekonomi Liberal, Serukan Khilafah $\sim$ INFOKOM HTI GARUT. Retrieved from http://infokomgarut.blogspot.com/2016/09/warga-garut-tolak-demokrasi-danekonomi.html

Karagiannis, E., \& McCauley, C. (2006). Hizb ut-Tahrir al-Islami: Evaluating the Threat Posed by a Radical Islamic Group That Remains Nonviolent. Terrorism and Political Violence, 18(2), 315-334. http://doi.org/10.1080/09546550600570168 
Mastur. (2011, February 25). Respon Mahasiswa Muslim UNY Terhadap Pemikiran Khilafah Hizbut Tahrir Indonesia (HTI). UIN Sunan Kalijaga.

Mohamed Osman, M. N. (2010). Reviving the Caliphate in the Nusantara: Hizbut Tahrir Indonesia's Mobilization Strategy and Its Impact in Indonesia. Terrorism and Political Violence, 22(4), 601-622. http://doi.org/10.1080/09546553.2010.496317

Nasir, M. A. (2014). The 'Ulamā', Fatāwā and Challenges to Democracy in Contemporary Indonesia. Islam and Christian-Muslim Relations, 25(4), 489-505. http://doi.org/10.1080/09596410.2014.926598

Orofino, E. (2015). Intellectual radicals challenging the state: the case of Hizb ut-Tahrir in the west. Contemporary Social Science, 10(4), 401-412. http://doi.org/10.1080/21582041.2016.1236212

Riyadi, D. S. (2008). Analisis Terhadap Konsep Khilafah Menurut Hizbut Tahrir. Institut Agama Islam Negeri Walisongo.

Salim, A., \& Ubaidillah, A. (2000). Pendidikan kewargaan: demokrasi, HAM \& masyarakat madani. Jakarta: IAIN Jakarta Press.

Selly, R. (2008). Globalisasi Dan Kebangkitan Khilafah Islamiyah Dalam Perspektif Pemikiran Hizbut Tahrir. Universitas Islam Negeri Syarif Hidayatullah.

Seo, M. (2012). Defining "religious" in Indonesia: toward neither an Islamic nor a secular state. Citizenship Studies, 16(8), 1045-1058. http://doi.org/10.1080/13621025.2012.735028

Yilmaz, I. (2010). The Varied Performance of Hizb ut-Tahrir: Success in Britain and Uzbekistan and Stalemate in Egypt and Turkey. Journal of Muslim Minority Affairs, 30(4), 501-517. http://doi.org/10.1080/13602004.2010.533448

Zulfadli. (2010, June 24). Infiltrasi Gerakan Hizbut Tahrir di Yogyakarta. UIN Sunan Kalijaga. 